Prepared for the U.S. Department of Energy

under Contract DE-AC05-76RL01830

\title{
Targeted Energy Efficiency Expert Evaluation (E4) Report: \\ Neal Smith Federal Building, \\ Des Moines, IA
}

J Goddard

N Fernandez

R Underhill

K Gowri

March 2013

Pacific Northwest

NATIONAL LABORATORY

Proudly Operated by Battelle Since 1965 


\section{DISCLAIMER}

This documentation was prepared as an account of work sponsored by an agency of the United States Government. Neither the United States Government nor any agency thereof, nor Battelle Memorial Institute, nor any of their employees, makes any warranty, express or implied, or assumes any legal liability or responsibility for the accuracy, completeness, or usefulness of any information, apparatus, product, or process disclosed, or represents that its use would not infringe privately owned rights. Reference herein to any specific commercial product, process, or service by trade name, trademark, manufacturer, or otherwise does not necessarily constitute or imply its endorsement, recommendation, or favoring by the United States Government or any agency thereof, or Battelle Memorial Institute. The views and opinions of authors expressed herein do not necessarily state or reflect those of the United States Government or any agency thereof.

\section{PACIFIC NORTHWEST NATIONAL LABORATORY \\ operated by \\ BATTELLE \\ for the \\ UNITED STATES DEPARTMENT OF ENERGY \\ under Contract DE-AC05-76RL01830}

Printed in the United States of America

$$
\begin{aligned}
& \text { Available to DOE and DOE contractors from the } \\
& \text { Office of Scientific and Technical Information, } \\
& \text { P.O. Box 62, Oak Ridge, TN 37831-0062; } \\
& \text { ph: (865) 576-8401, fax: (865) 576-5728 } \\
& \text { email: reports@adonis.osti.gov }
\end{aligned}
$$

Available to the public from the National Technical Information Service,

U.S. Department of Commerce, 5285 Port Royal Rd., Springfield, VA 22161

ph: (800) 553-6847, fax: (703) 605-6900

email: orders@ntis.fedworld.gov

online ordering: http://www.ntis.gov/ordering.htm 


\section{Targeted Energy Efficiency Expert Evaluation (E4) Report: Neal Smith Federal Building, Des Moines, IA}

JK Goddard

N Fernandez

RM Underhill

K Gowri

March 2013

Prepared for

Federal Energy Management Program

U.S. Department of Energy

under Contract DE-AC05-76RL01830

Pacific Northwest National Laboratory

Richland, Washington 99352 


\section{Executive Summary}

Since 2007, PNNL has conducted Energy Efficiency Expert Evaluations (E4) field training and facility assessments in the Heartland Region (GSA Region 6) buildings to identify low-cost/no-cost opportunities that have the potential to reduce building energy use by up to 10 percent. Based on a follow-up study and feedback from operation and maintenance (O\&M) staff, it was recognized that only 50 percent of the recommended measures were implemented and the lack of control systems expertise was often found to be a major challenge in following up on the E4 recommendations. Hence the Region undertook a new initiative in 2011 to perform targeted E4 field audits to identify and train O\&M staff to monitor and implement control system measures to realize energy savings.

The Targeted E4 retuning process uses the building automation system (BAS) and the site metering data (ION or other if different) as the central tool in the investigation, monitoring and diagnosis of the operating condition of the building equipment and systems. The Targeted E4 process begins with virtual meetings between the Targeted E4 Team, Regional Energy Engineer, Building Managers/staff and O\&M contractor to review the BAS and key building systems. These meetings identify BAS trends to set up and save in the building BAS system, along with establishing a complete trend logging process. A minimum of 2-3 weeks of trend data is used before the first site visit to be analyzed by the Targeted E4 Team before arriving at the facility. Energy Charting and Metrics (ECAM) tool is used to process the data that results in several charts and graphs highlighting building performance along with individual HVAC system performance (air handlers, terminal boxes, chiller plant, hot water plant, etc.).

During the Targeted E4 process, particular emphasis is made to provide training and implementation assistance to O\&M staff. This training includes setting up and use trends and some graphical diagnostic aids pertinent to economizers and chiller performance. The onsite training emphasizes using trend data to evaluate hot/cold calls as well as diagnosis of the operating conditions of a particular piece of equipment and evaluating the actual schedules of equipment versus the actual hours of operations (including scheduled overtime utilities). Overall, the training focuses on optimizing set points, schedules and sequences to save energy without sacrificing the comfort of the occupants of the building. Training also focuses on steering the operators away from using overrides as a normal operating procedure, and to look at the system as a whole to make energy smart adjustments to the BAS. O\&M staff are also trained on how to adjust or reverse any control system changes made during the Targeted E4 process, in the event that the changes do not work as expected. In addition, the Targeted E4 Team provided phone and email support to the building staff and O\&M staff during the retuning process.

A dedicated regional energy engineer (Linda Baschnagel) is assigned to coordinate and facilitate all Targeted E4 efforts, provide metered data reports and provide support to site staff with implementation of the recommended measures and ongoing monitoring of the building performance. This coordination is found to be critical for the success of the Targeted E4 process.

This report summarizes the targeted E4 measures identified and implemented in the Neal Smith Federal Building. The targeted E4 approach involved an initial site visit to identify energy savings opportunities, implement some of the identified measures and train O\&M staff to continue the implementation process. A second follow-up visit and continued O\&M staff support was provided to review and ensure all measures were implemented correctly. Each targeted E4 measure was modeled in 
EnergyPlus and expected savings were evaluated before implementing the measures. These savings estimates were validated using metered data available at this site. This report also includes an action plan for O\&M staff to monitor and improve the effectiveness of the targeted E4 measures identified and implemented.

A total of nine energy savings measures were identified and eight of them were fully or partially implemented. The estimated energy savings based on an energy model of all the identified measures is 13.2 percent and the savings for all of the measures as implemented is 10.6 percent. An analysis of utility billing data shows that (as of December 2012) Neal Smith's annual building energy use has decreased by 21.7 percent after weather correction, including the impact of recovery act projects and six months of Targeted E4 measures implementation. Based on the analysis of ION data collected since Targeted E4 implementations, Neal Smith Building annual energy use is expected to be $40.2 \mathrm{kBtu} / \mathrm{sf}$ by end of FY2013, representing 21.5 percent reduction compared to FY2012. The current EnergyStar rating for Neal Smith Building is 97 which shows an improvement of four points from March 2012. 


\section{Table of Contents}

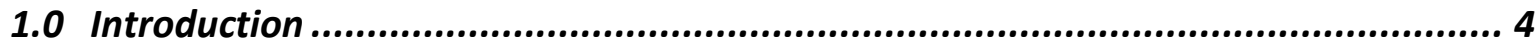

2.0 Recommended Measures......................................................................6 6

2.1 Measure 1: Scheduling of each individual tenant area per occupied schedule 6

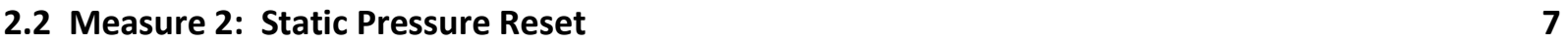

2.3 Measure 3: Supply Air Temperature Reset $\quad 8$

2.4 Measure 4: Hot Water Differential Pressure Reset 9

2.5 Measure 5: Hot Water Temperature Reset $\quad 10$

2.6 Measure 6: Chilled Water Temperature Reset $\quad 11$

2.7 Measure 7: Chilled Water Differential Pressure Reset 12

2.8 Measure 8: Widen VAV Box Thermostat Deadband 13

2.9 Measure 9: Discharge Air Temperature Reset for Air Handler G 14

2.10 Miscellaneous Observations/Recommendations: 15

3.0 Measurement and Verification of Energy Savings ......................................16

4.0 Recommended Monitoring Plan ............................................................20

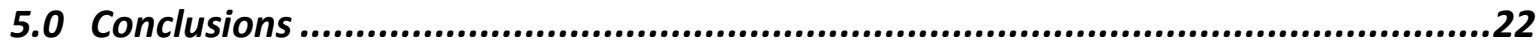




\subsection{Introduction}

As part of a new targeted E4 initiative by the Heartland Region, PNNL staff members conducted an energy efficiency field audit at Neal Smith Federal Building in Des Moines, IA during March 12-13, 2012. During this visit, discussions with GSA staff and review of mechanical, electrical and control systems were performed. The objective of the first targeted E4 field visit was to work with building O\&M staff to directly implement the identified measures. However, two constraints prevented the E4 team from implementing any of the measures during the initial visit. First, a project to upgrade air handlers and VAV networks had not been completed. This meant that GSA had not signed off on the contractor's installation and the control of the new systems had not been fully commissioned. Second, since the BAS is under warranty, any recommended changes could not be implemented at the time of the initial visit. PNNL's actions were limited to a building walk-down, identification of opportunities and potential measures on the BAS, programming of BAS trending and diagnostic capabilities, and programming the capability to easily implement the recommended measures ${ }^{1}$.

PNNL returned to Neil Smith in late June of 2012 to implement targeted E4 measures that could not be implemented on the March visit. Neil Smith staff agreed to seven of the nine recommended measures, which were implemented by PNNL. An additional recommended measure (widening thermostat deadbands) was partially implemented by the controls contractor following PNNL's recommendation in March. Site staff are holding off on implementing another measure: independent scheduling of individual tenant areas. This report summarizes low-cost/no-cost opportunities identified and building control system changes that were implemented during these two visits.

Table 1 summarizes the nine energy saving measures that were identified and/or implemented. (A detailed discussion on each of these measures is included in the Measure Summary section of this report.) A preliminary estimate of the potential energy saving for each measure has been calculated using an energy model of the building (developed in EnergyPlus). Several of the measures were implemented at the site by PNNL staff or some are recommendations for Neal Smith staff to implement.

Table 1. Summary of Energy Efficiency Measures and the Expected Savings

\begin{tabular}{|c|c|c|c|}
\hline No. & Description & $\begin{array}{c}\text { Expected } \\
\text { Savings (\%) }\end{array}$ & $\begin{array}{c}\text { Status / } \\
\text { Implementation Notes }\end{array}$ \\
\hline 1 & $\begin{array}{l}\text { Scheduling of each individual tenant area } \\
\text { per occupied schedule }\end{array}$ & 1.3 & $\begin{array}{l}\text { Not implemented. Site staff holding off on the } \\
\text { recommendation }\end{array}$ \\
\hline 2 & Static Pressure Reset & 1.9 & Implemented during June Targeted-E4 visit \\
\hline 3 & Supply air temperature reset & 7.6 & Implemented during June Targeted-E4 visit \\
\hline 4 & Hot water differential pressure reset & -0.2 & Implemented during June Targeted-E4 visit \\
\hline 5 & Hot water temperature reset & $\begin{array}{l}\text { Unknown, } \\
\text { minimal }\end{array}$ & Implemented during June Targeted-E4 visit \\
\hline 6 & Chilled water temperature reset & 0.1 & $\begin{array}{l}\text { Partially implemented remotely after June visit. } \\
\text { Chillers do not accept remote changes to set point }\end{array}$ \\
\hline 7 & Chilled water differential pressure reset & 1.4 & Implemented during June Targeted-E4 visit \\
\hline 8 & Widen VAV Thermostat Deadband & 1.7 & $\begin{array}{l}\text { Discussed measure in-depth with AHU installer. } \\
\text { Dead bands were eventually widened to } 1^{\circ} \mathrm{F} \text {, but } \\
\text { staff holding off on full } 2^{\circ} \mathrm{F} \text { dead band adjustment }\end{array}$ \\
\hline 9 & $\begin{array}{l}\text { Discharge Air Temperature Reset for Air } \\
\text { Handler G }\end{array}$ & $\begin{array}{c}\text { Modeled as } \\
\text { part of \#3 }\end{array}$ & Implemented during June Targeted-E4 visit \\
\hline
\end{tabular}

\footnotetext{
${ }^{1}$ This involved developing the program structure for several measures within the BAS and including a "switch" that kept each measure disabled until the site was ready to implement.
}

Mar-13 Targeted E4 Final Report: Neal Smith Federal Building 
Figure 1 shows the modeled total building energy savings resulting from the implementation of measures individually and in combination. When combined, the model predicts that measures 2-4 and 69 (which are fully implemented) will together yield 10.6 percent annual building energy savings. Additional savings are possible from Measure 5 (hot water temperature reset), but cannot be modeled appropriately. With the additions of Measure 1 (not yet implemented) and the implementation of Measure 8 as originally recommended, the model predicts a total possible savings of 13.2 percent.

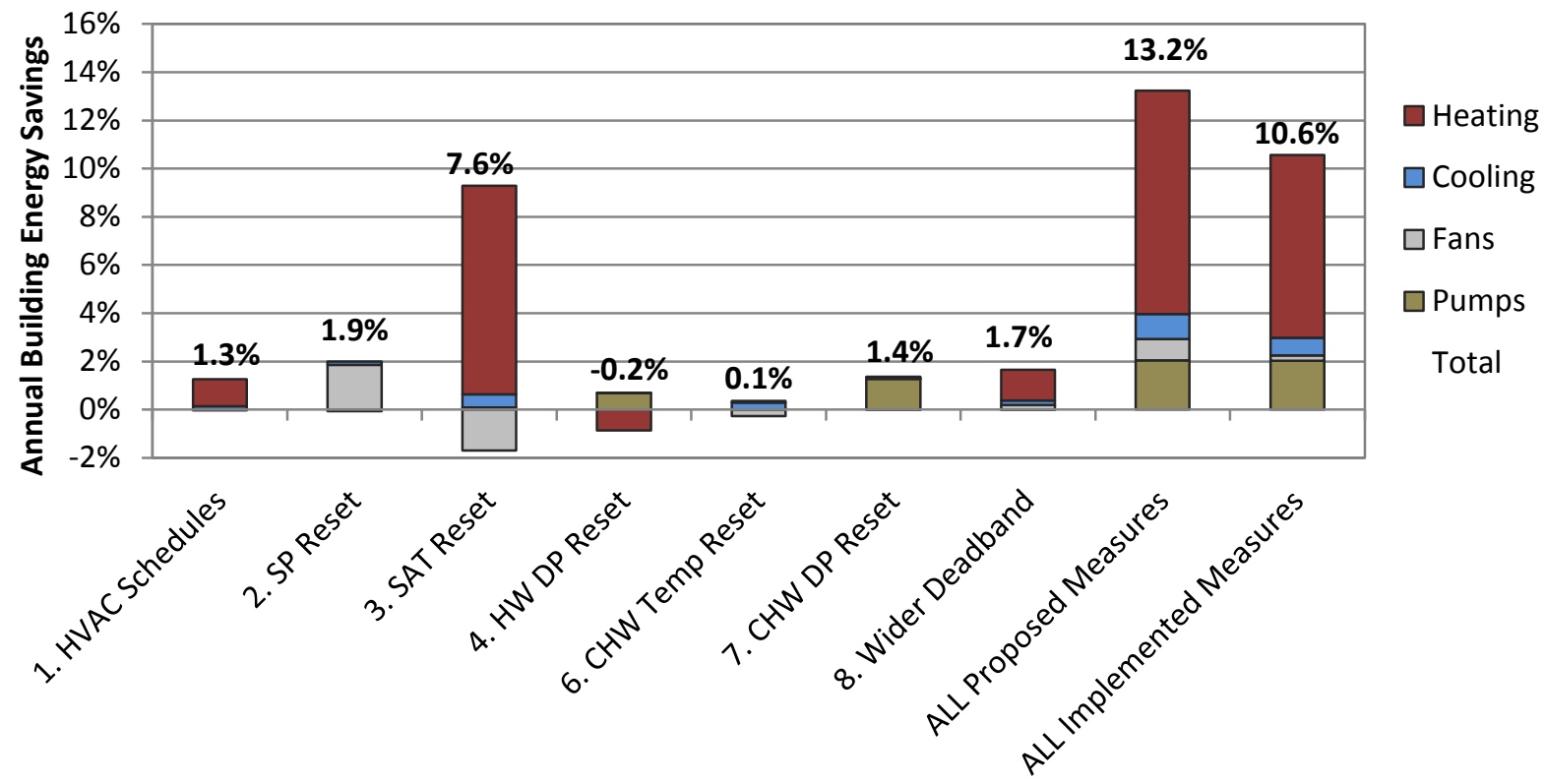

Figure 1. Modeled Annual Building Energy Savings Resulting from Implementation of Targeted-E4 Measures

Section 2 of the report summarizes each of the recommended measures, implementation strategy and estimated energy savings. Section 3 presents the measurement and verification of energy savings using the metered data available from the site and utility billing data obtained from the GSA energy use summary reports. The verification is done by comparing weather adjusted energy use before and after the targeted E4 measures implementation. A list of recommendations for continued monitoring and future implementation actions are presented in Section 4, followed by general conclusions of the impact of targeted E4 at Neal Smith in Section 5. 


\subsection{Recommended Measures}

\begin{tabular}{|c|}
\hline $\begin{array}{l}2.1 \text { Measure 1: Scheduling of each individual tenant area per } \\
\text { occupied schedule }\end{array}$ \\
\hline Observation: \\
\hline $\begin{array}{l}\text { - AHU fans are observed to be running } 12 \text { hours per day. Neal Smith Building management staff } \\
\text { would like to reduce the operating hours to } 10 \text { hours per day. This is consistent with the contract } \\
\text { that HVAC systems will run } 10 \text { hours per day. } \\
\text { - Current operation is that fans are scheduled to start at 6:00 am and run until 6:00pm. }\end{array}$ \\
\hline Recommendation Log: \\
\hline $\begin{array}{l}\text { - March 2012: Reduce fan energy by scheduling each tenant's thermostat setback schedules at the } \\
\text { zone level for only the hours that they are occupied. This will allow the fan to slow and provide } \\
\text { air to areas that are occupied. }\end{array}$ \\
\hline Implementation Details/Action Plan: \\
\hline $\begin{array}{l}\text { - March 2012: GSA to provide a detailed plan of tenant area and occupied hours. The plan should } \\
\text { have the VAV boxes listed with the associated area to speed up implementation time } \\
\text { - June 2012: Currently on hold by the field office. }\end{array}$ \\
\hline Estimated Savings: \\
\hline - 1.3 percent annual building energy savings ( 0.2 percent electricity, 2.6 percent gas) \\
\hline
\end{tabular}




\subsection{Measure 2: Static Pressure Reset \\ Observation: \\ - The new air handlers currently have a static pressure reset that is based on keeping the highest- demand VAV box damper served by each air handler at 95 percent open. This type of control may be too conservative.}

\section{Recommendation Log:}

- March 2012: Recommend using the average damper position as the control variable for the fan static pressure set point instead of the current 'high select' method.

- Use 1.5 inches water column as the high static pressure set point for average damper positions above 60 percent and 0.7 inches water column as the low set point, for average damper positions below 40 percent.

\section{Implementation Details/Action Plan:}

- March 2012: PNNL did a test implementation of this measure on one air handler (AHU-E). Figure 2 shows trended static pressure set points and fan power consumption for this fan as well as its 'sister fan', AHU-F (serving the other half of the same set of floors), during the same 20 hour period. Static Pressure set points and fan power consumption were significantly lower on average for AHU-E compared to AHU-F.

- June 2012: AHU's C, D, E, F have supply duct static pressure set points implemented. AHU-C set points are 0.3/1.2 in. wc. AHU-D set points are 0.4/1.3 in. wc. AHU-E set points are 0.3/1.2 in. wc. AHU-F set points are 0.3/1.2 in. wc. All four air handlers fans use feedback from the average damper position for all the boxes in their network. The average damper position set point is 60 percent.

\section{Estimated Savings:}

- $\quad 1.9$ percent annual building energy savings (3.6 percent electricity, -0.1 percent gas)

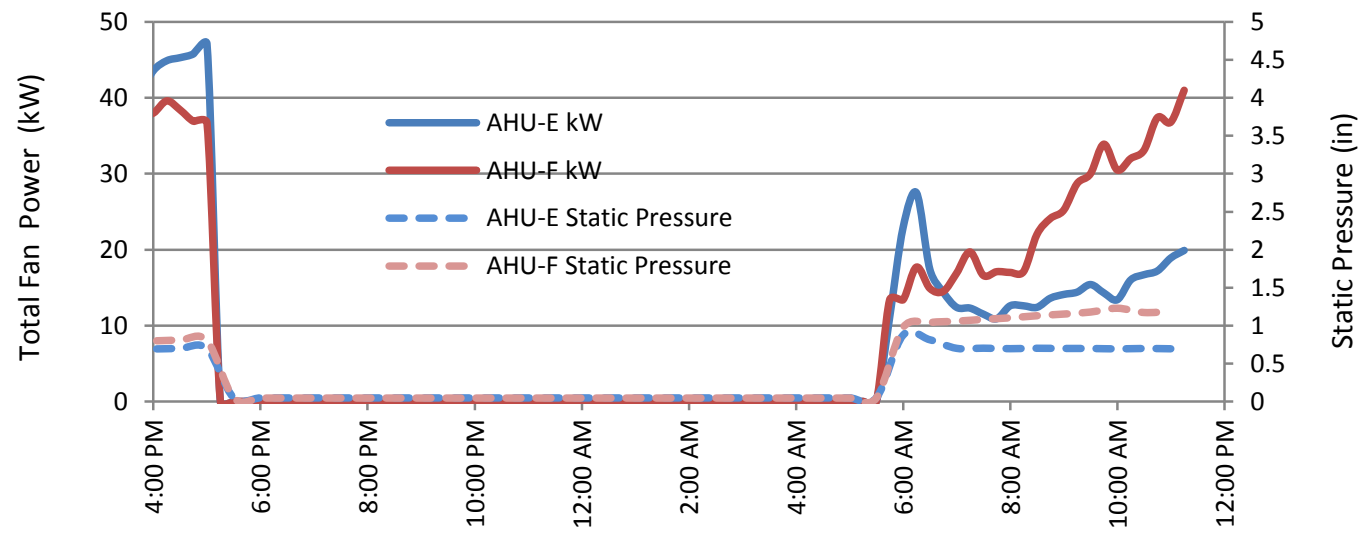

Figure 2. Static Pressure Set points and Fan Power Consumption for Similar Fans with and without Static Pressure Reset 


\begin{tabular}{|c|}
\hline 2.3 Measure 3: Supply Air Temperature Reset \\
\hline Observation: \\
\hline $\begin{array}{l}\text { - At the time of the initial site visit, the building uses supply air temperature reset with a range of } \\
\text { supply air set points of } 53^{\circ} \mathrm{F}-60^{\circ} \mathrm{F} \text {. The existing control code calculates the set point value based } \\
\text { on outdoor-air temperature. The discharge air temperature set point is reset between a low-limit } \\
\text { of } 53^{\circ} \mathrm{F} \text { when outdoor-air temperature is greater than } 56^{\circ} \mathrm{F} \text { and a high limit of } 60^{\circ} \mathrm{F} \text { when it is less } \\
\text { than } 40^{\circ} \mathrm{F} \text {. } \\
\text { During the March site visit, the chillers were not operational and the outdoor-air temperature was } \\
\text { around } 70^{\circ} \mathrm{F} \text {. The building was at a comfortable temperature and there were no occupant } \\
\text { complaints. At this seemingly high outdoor-air temperature, the building did not need heating or } \\
\text { cooling. This is a change from the way the old system operated. Had the chiller been on and the } \\
\text { discharge air temperature been allowed to reset to } 53^{\circ} \mathrm{F} \text { (as it had been able to earlier in the month } \\
\text { when the economizer could meet the } 53^{\circ} \mathrm{F} \text { set point) there would likely have been cold } \\
\text { complaints from occupants. } \\
\text { This is a new building from the standpoint of the HVAC system, consequently the personality of } \\
\text { the building has changed. The operations of the HVAC systems need to be watched to re-learn } \\
\text { the personality of the building. O\&M staff should develop an operating plan based on these and } \\
\text { similar observations to only run the heating and cooling systems when the building truly needs } \\
\text { the systems to run. }\end{array}$ \\
\hline Recommendation Log: \\
\hline $\begin{array}{l}\text { - March 2012: Change the supply air temperature reset strategy to use the return air temperature as } \\
\text { the control variable. } \\
\text { - Reset the supply air temperature set point from a low of } 55^{\circ} \mathrm{F} \text { when the return air temperature is } \\
\text { at or above } 75^{\circ} \mathrm{F} \text { to a high of } 70^{\circ} \mathrm{F} \text { when the return air temperature is at or below } 70^{\circ} \mathrm{F} \text {. }\end{array}$ \\
\hline Implementation Details/Action Plan: \\
\hline $\begin{array}{l}\text { - March 2012: Implemented supply air temperature reset for the following air handlers: C, D, E, F. } \\
\text { - Adjusted the return air temperature, hi-limit to } 78^{\circ} \mathrm{F} \text {. } \\
\text { - June 2012: Further tuning took place during the June } 2012 \text { site visit. }\end{array}$ \\
\hline Estimated Savings: \\
\hline - 7.6 percent annual building energy savings (-1.9 percent electricity, 19.6 percent gas) \\
\hline
\end{tabular}




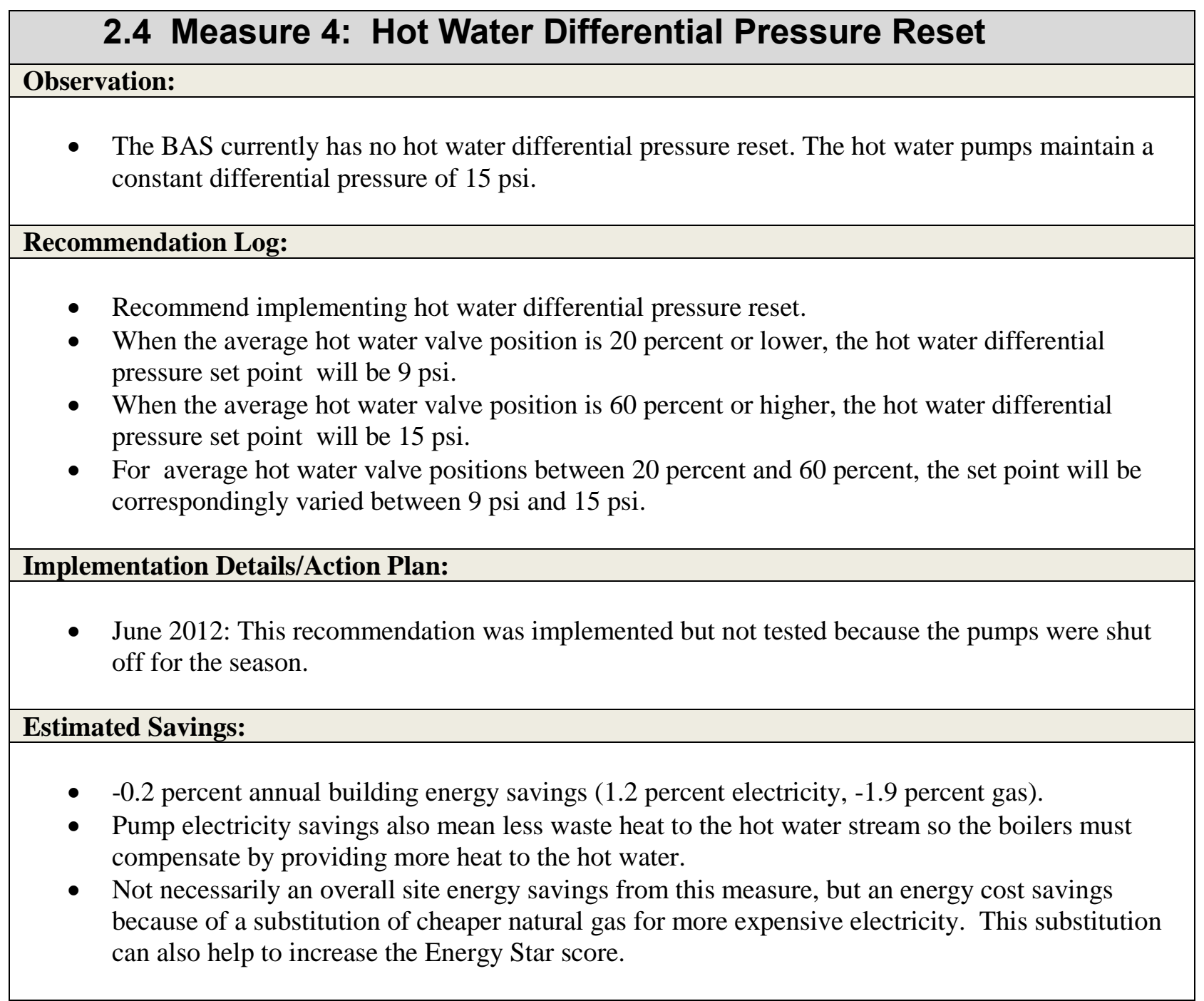




\subsection{Measure 5: Hot Water Temperature Reset}

\section{Observation:}

- The hot water temperature set point is currently reset based on outdoor-air temperature.

- Outdoor-air temperature reset range is $40^{\circ} \mathrm{F}$ for the low temperature and $70^{\circ} \mathrm{F}$ for the high temperature.

- Hot water reset temperature is $120^{\circ} \mathrm{F}$ for the low and $180^{\circ} \mathrm{F}$ for the high set points.

- The hot water system is not permitted to operate at an outdoor-air temperature that is greater than $54^{\circ} \mathrm{F}$. Consequently the hot water reset never reaches its lowest possible temperature set point which is $120^{\circ} \mathrm{F}$ before the system is turned off.

- For outdoor-air temperature between $40^{\circ} \mathrm{F}$ and $70^{\circ} \mathrm{F}$, the hot water temperature set point will be correspondingly varied between $180^{\circ} \mathrm{F}$ and $120^{\circ} \mathrm{F}$.

\section{Recommendation Log:}

- March 2012: Recommend revising hot water temperature reset set points for better performance and energy savings.

- Move the low outdoor-air temperature set point to $10^{\circ} \mathrm{F}$ and lower the high outdoor-air temperature set point to $50^{\circ} \mathrm{F}$.

- Leave the hot water reset temperatures at $180^{\circ} \mathrm{F}$ for the high temperature set point and $120^{\circ} \mathrm{F}$ for the low temperature set point.

- For outdoor-air temperature between $10^{\circ} \mathrm{F}$ and $50^{\circ} \mathrm{F}$, the set point will be linearly varied between $180^{\circ} \mathrm{F}$ and $120^{\circ} \mathrm{F}$.

- Leave the outdoor-air temperature hot water system lockout temperature at $54^{\circ} \mathrm{F}$.

\section{Implementation Details/Action Plan:}

- Implemented this measure during the June follow-up visit.

- O\&M staff indicated that the pans (bottom of the Aerco condensing boilers and connected to the stack venting systems) are rusting out. This would be consistent with a poorly designed venting system that does not remove condensation adequately. Unless this issue is resolved, the hot water temperature reset may not be implemented and a capital project will be recommended to address this in the future.

- This recommendation was implemented but not tested due to the summer season.

\section{Estimated Savings:}

- Difficult to model savings due to complexity of energy savings mechanisms. 


\begin{tabular}{|c|}
\hline 2.6 Measure 6: Chilled Water Temperature Reset \\
\hline Observation: \\
\hline $\begin{array}{l}\text { - Chilled water temperature is set at a constant temperature set point of } 44^{\circ} \mathrm{F} \\
\text { - The chilled water temperature set point is not currently reset. }\end{array}$ \\
\hline Recommendation Log: \\
\hline $\begin{array}{l}\text { - March 2012: Recommend implementing chilled water temperature reset. } \\
\text { - When the average chilled water valve position is } 20 \text { percent or lower, the chilled water } \\
\text { temperature set point will be } 50^{\circ} \mathrm{F} \text {. } \\
\text { - When the average chilled water valve position is } 60 \text { percent or higher, the chilled water } \\
\text { temperature set point will be } 44^{\circ} \mathrm{F} \text {. } \\
\text { - For average chilled water valve positions between } 20 \text { percent and } 60 \text { percent, the set point will be } \\
\text { linearly varied between } 50^{\circ} \mathrm{F} \text { and } 44^{\circ} \mathrm{F} \text {. }\end{array}$ \\
\hline Implementation Details/Action Plan: \\
\hline $\begin{array}{l}\text { - March 2012: GSA to provide a detailed plan of tenant area and occupied hours. The plan should } \\
\text { have the VAV boxes listed with the associated area to speed up implementation time } \\
\text { - June 2012: Currently on hold by the field office. }\end{array}$ \\
\hline Estimated Savings: \\
\hline $\begin{array}{l}\text { - June 2012: Partially implemented, remotely, after the June follow-up visit. } \\
\text { - Chiller set point cannot be adjusted remotely, building staff will implement this in the near future. }\end{array}$ \\
\hline
\end{tabular}




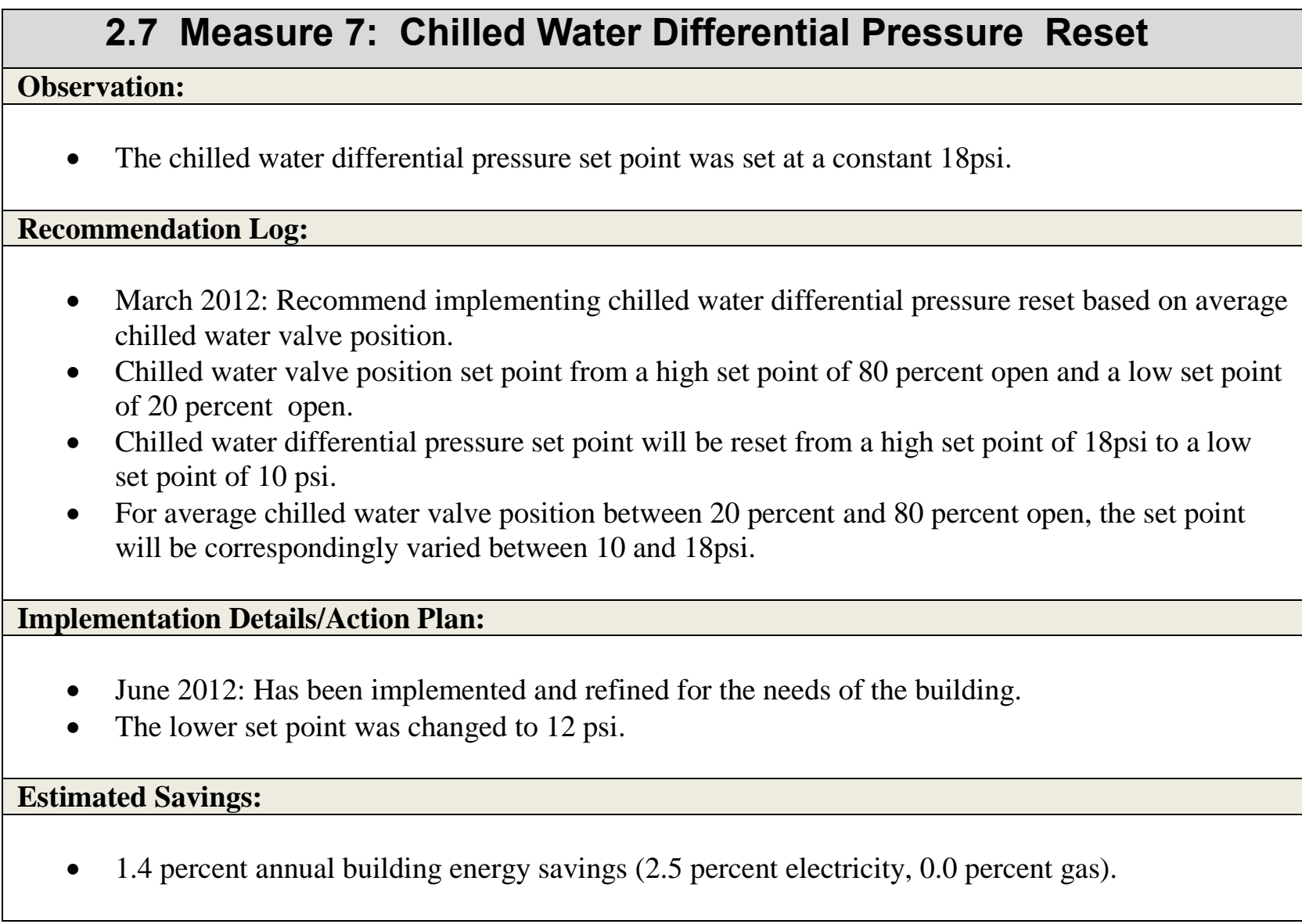




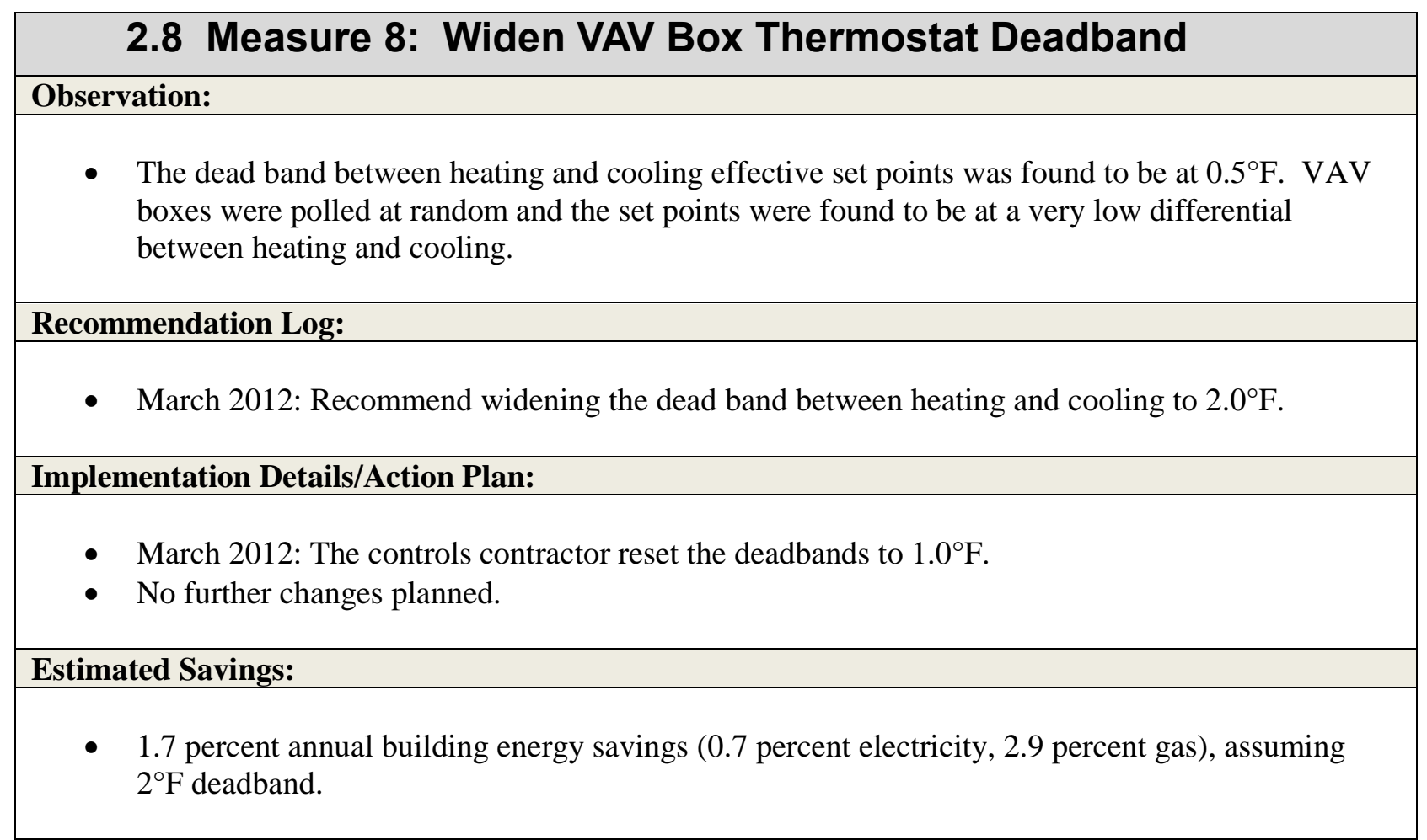




\subsection{Miscellaneous Observations/Recommendations:}

- UV lamps are interlocked with the supply fan to shut off. If they could be interlocked with the chiller and fan, this would save additional energy when chillers are not operating (no condensing occurring).

- The basement mechanical room housing AHU-E and AHU-F has un-insulated heating hot water lines in several locations at the ceiling level. They should be insulated.

- There is a heating hot water loop that routes through the soffit area, below the 2 nd floor that is cantilevered over the exterior of the building on all sides. The loop apparently is not insulated, so that convection of heat is occurring as the loop has heated water pumped through it. It is not clear if this system is needed (providing heat to protect other piping from freezing, providing heat to help the 2nd floor during cold weather - due to poor or no insulation). The pump for this loop (in the basement mechanical room) was observed to be running, but the gas-fired heater was off. The loop temperature was $60^{\circ} \mathrm{F}$ (ambient). The O\&M staff indicated that this pump was running to extract every BTU of heat from it, before shutting it off. It is not clear that $60^{\circ} \mathrm{F}$ water has any more heat to give off when the surrounding space is at the same temperature. This system should be further evaluated.

- The basement exhaust fan (EF-1) was found to be running 24/7. This fan apparently exhausts the basement mechanical rooms, but probably should only run if temperatures are too warm. It is unclear if this fan is even on Metasys control (for scheduling, etc.). No one could specifically state why this fan was running or if it even served a purpose. It was stated that this fan is a legacy to past operations and since the building has changed so much, it needs to be reviewed for decision on whether this fan needs to run or not. This exhaust fan (if not needed) could be hurting the facility operations. When this fan is operational, it will hinder trying to resolve negative issues in the building. If this fan is on Metasys control, recommend shutting off at night and weekends or configuring for temperature only control.

- The penthouse exhaust fan (EF-2) was found to be running 24/7. This fan apparently exhausts basement shop areas (when past practices including welding and cutting wood - creating dust, etc). It is unclear if this fan is on Metasys control (for scheduling, etc.). No one could specifically state why this fan was running or its purpose. It was stated that this fan is a legacy to past operations and since the building has changed so much, it needs to be reviewed for a decision on operation. This exhaust fan (if not needed) could be hurting the facility operations. When this fan is operational, it will hinder trying to resolve negative issues in the building. If this fan is on Metasys control, recommend shutting off at night and weekends or shutting off completely if there is no valid reason for it to operate. 


\subsection{Measurement and Verification of Energy Savings}

Neal Smith Building has advanced metering capability that can provide electric demand data at 15 minute intervals which can be processed with Schneider PowerLogic ION Enterprise Energy Management Software, referred as ION meter data in this report. GSA staff provided monthly updates of ION meter data since February 2012. ION data for similar months in past years is typically preferred in order to establish a baseline from which to establish savings. The baseline for Targeted-E4 savings at Neal Smith, however, is not the building's energy consumption during the previous year, but its consumption patterns since completion of installation of the air handler and VAV systems in late December 2011. With this in mind, baseline patterns (as a function of weather) of electricity consumption for the cooling season have been taken from ION data in the same cooling season before Targeted-E4 implementation (which occurred in June 2012), and baseline patterns for "shoulder months" (moderate weather) were taken from ION data in the spring of 2012.

Figure 3 shows the average electricity consumption by hour of the day and day type for September versus May (two months with similar average temperatures). The ION analysis for this month shows that much of the savings during this late summer period is coming from reduced electricity consumption during occupied hours.

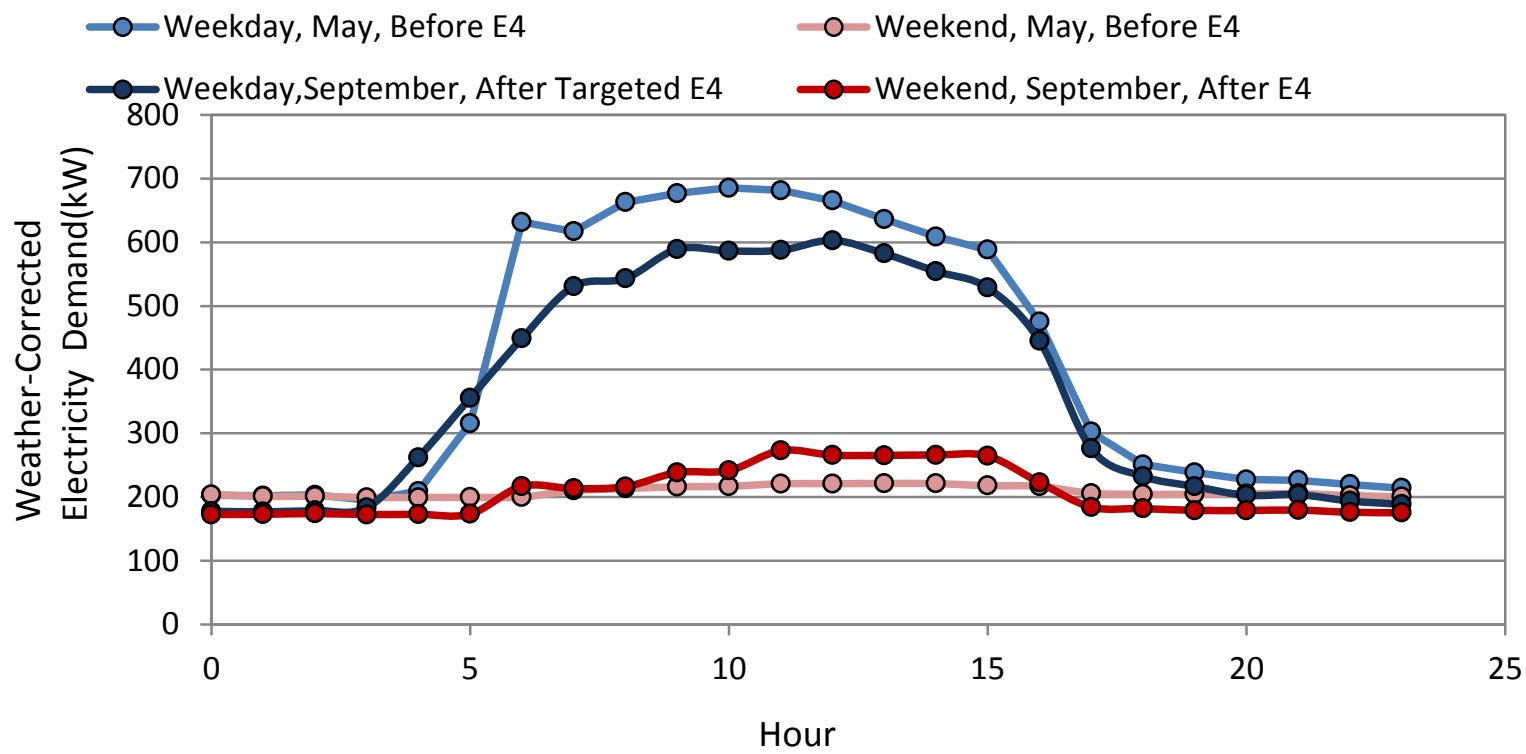

Figure 3. Neal Smith ION comparison: May versus September 2012 Electricity consumption

Figure 4 shows a comparison of monthly Targeted-E4 electricity savings from the ION analysis, compared with monthly predicted energy savings from the EnergyPlus 'All Implemented Measures' model presented earlier in Figure1. With the exception of July, The ION analysis estimated savings have generally been significantly higher than the modeled electricity savings. On average, ION-estimated savings have been 80 percent higher than modeled savings. 


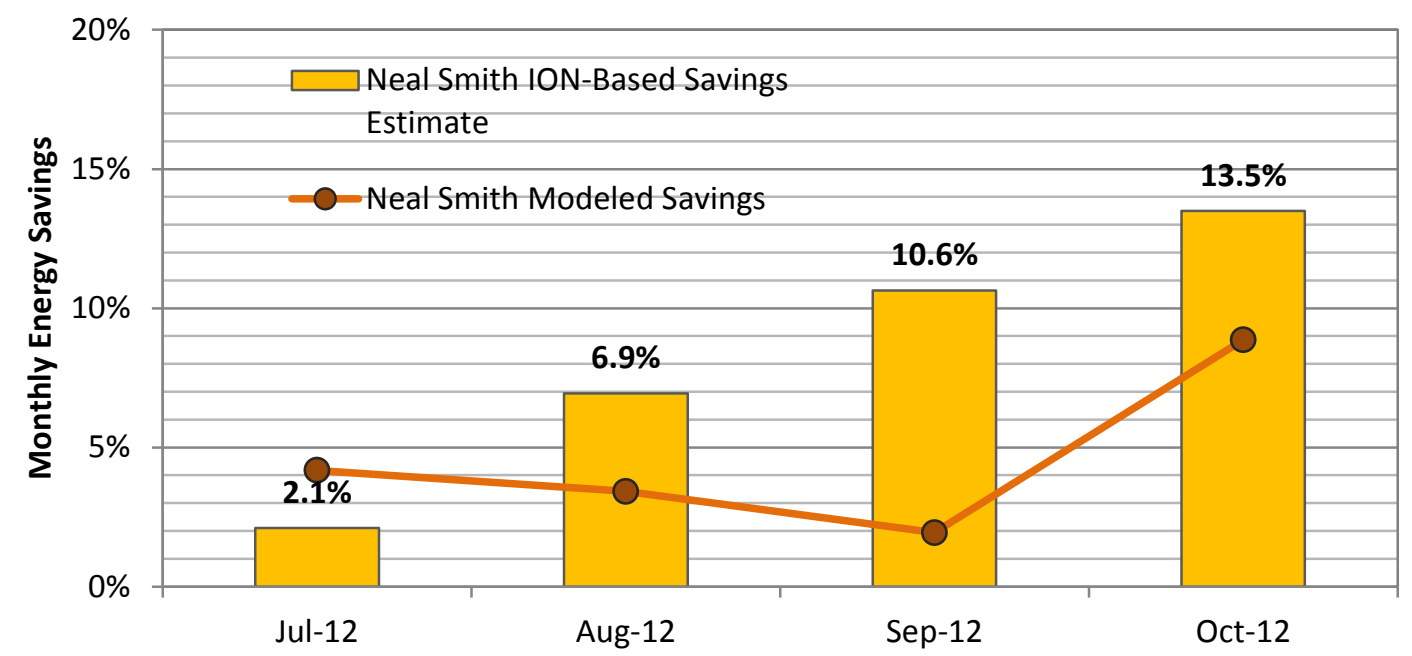

Figure 4. Electricity Savings: A comparison of ION versus modeled savings from EnergyPlus

To estimate natural gas energy savings, an analysis of EUAS gas billing data for the calendar year 2012 was performed (see Figure 5). Data from the months of January through May 2012 were used as the post-ARRA and Pre-Targeted-E4 baseline. Data from the months of September 2012 through December 2012 were used for the Post-Targeted E4 Analysis period. Gas consumption in each billing period is plotted as a function of the number of heating degree-days in each billing period. A very clear and very large energy reduction pattern is evident from this graph. Differences between the two trend lines indicate a 39 percent reduction in natural gas energy consumption for comparable heating demand levels. The EnergyPlus model predicted a 16.9 percent savings in gas consumption. Observed savings have thus far been over twice the predicted savings.

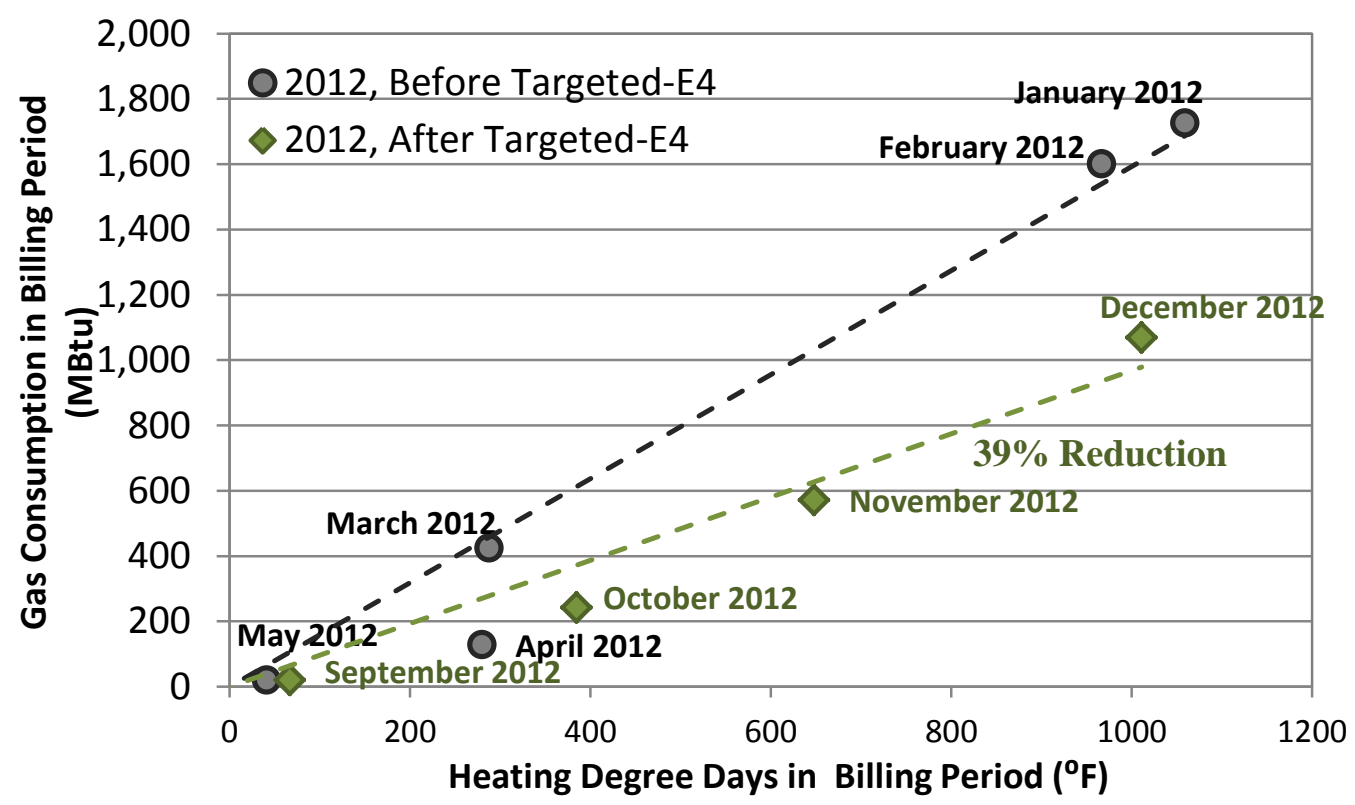

Figure 5. 2012 EUAS Gas Consumption Patterns Before and After Targeted-E4 
Accounting for gas and electricity together, observed energy reductions in Neal Smith have been about twice the model's predicted savings. The model predicted a total energy savings of 10.6 percent, including 5.4 percent electricity savings and 16.9 percent gas savings. If observed trends since the E4 visit continue, annual savings in electricity are expected to be 9.7 percent compared to the post-ARRA baseline, and actual gas savings are expected to be 39 percent, for a total savings of 22.3 percent. This would bring the weather-corrected Pre-Targeted-E4 energy use intensity (EUI) down from $56.5 \mathrm{kBtu} / \mathrm{sf}$ in May 2012 to $40.2 \mathrm{kBtu} / \mathrm{sf}$ by May 2013 .

Figure 6 shows rolling 12-month actual and weather-corrected EUIs for Neal Smith since December 2009. Savings from ARRA improvements are evident towards the end of 2011 as a steep drop in consumption. Further savings from Targeted-E4 are evident as another steep drop from the post-ARRA trend. Figure 6 shows the current (as of December 2012) weather-corrected EUI at $47.2 \mathrm{kBtu} / \mathrm{sf}$, with the raw EUI at $42.0 \mathrm{kBtu} / \mathrm{sf}$. This represents 28 percent actual and 21.7 percent weather-corrected drop in EUI from December 2011 to December 2012 which includes the impact of ARRA projects and six months of Targeted E4 implementations.

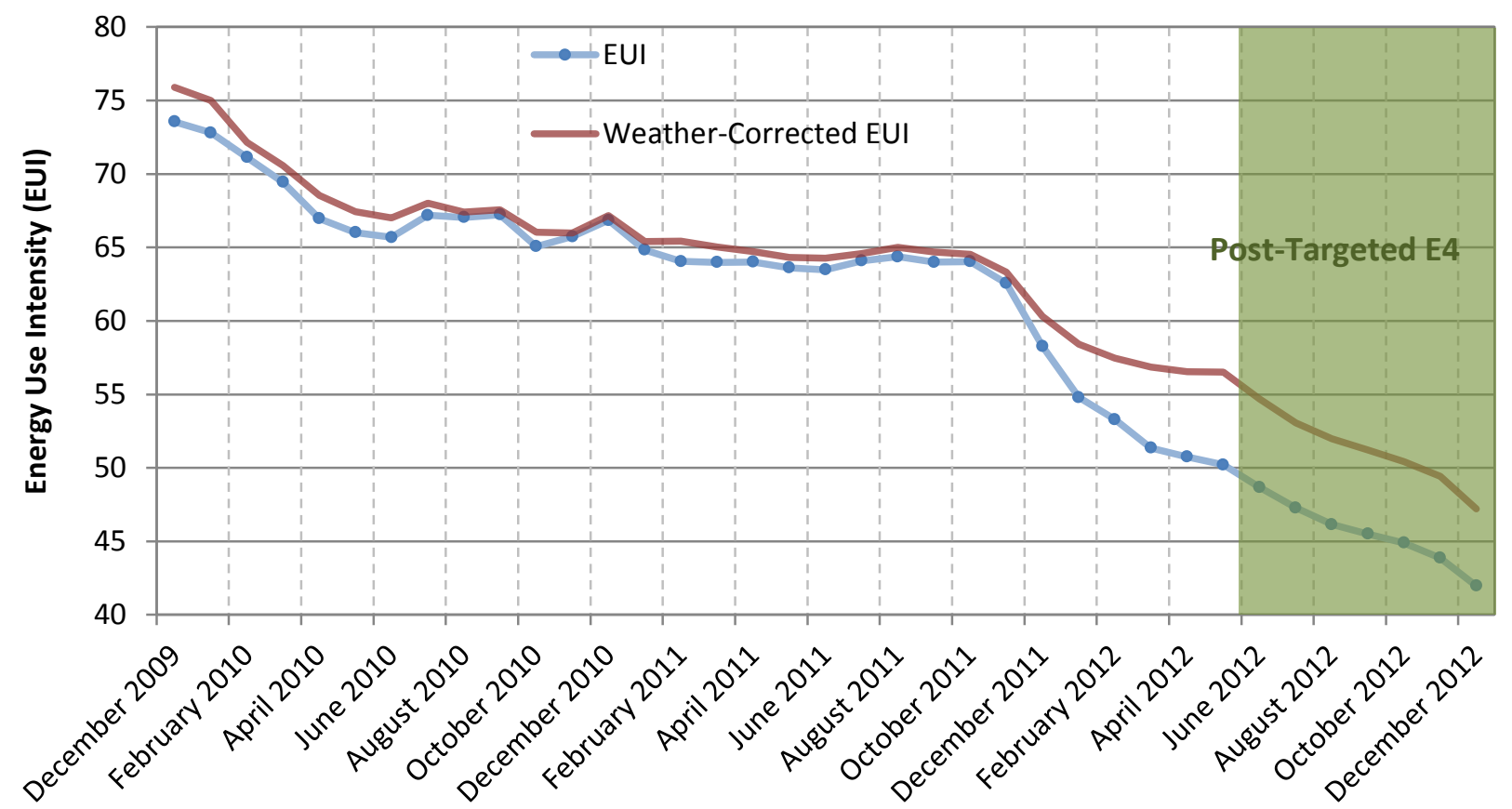

Figure 6. EUAS (Utility Bill) Analysis- Rolling 12-month EUI since December 2009

Figure 7 shows a history of energy consumption at Neal Smith during the past five years and projected energy consumption by the end of FY2013, using EUI as the metric for comparison. Based on observed changes in Energy consumption it is estimated that the ARRA projects were responsible for reducing the weather-corrected EUI from 64.7 to 51.0 (22 percent savings). The E4 implementation came towards the end of FY2012, so there was little difference between the modeled savings on top of the ARRA projects both with and without Targeted-E4 measures. For FY2013, according to the model, predicted energy savings is expected to bring the EUI down to $45 \mathrm{kBtu} / \mathrm{sf}$. As mentioned above, with the current trend of savings observed from ION data, the weather-corrected EUI in FY2013 is expected to be $40.2 \mathrm{kBtu} / \mathrm{sf}$ which represents 21.5 percent reduction compared to FY2012. 


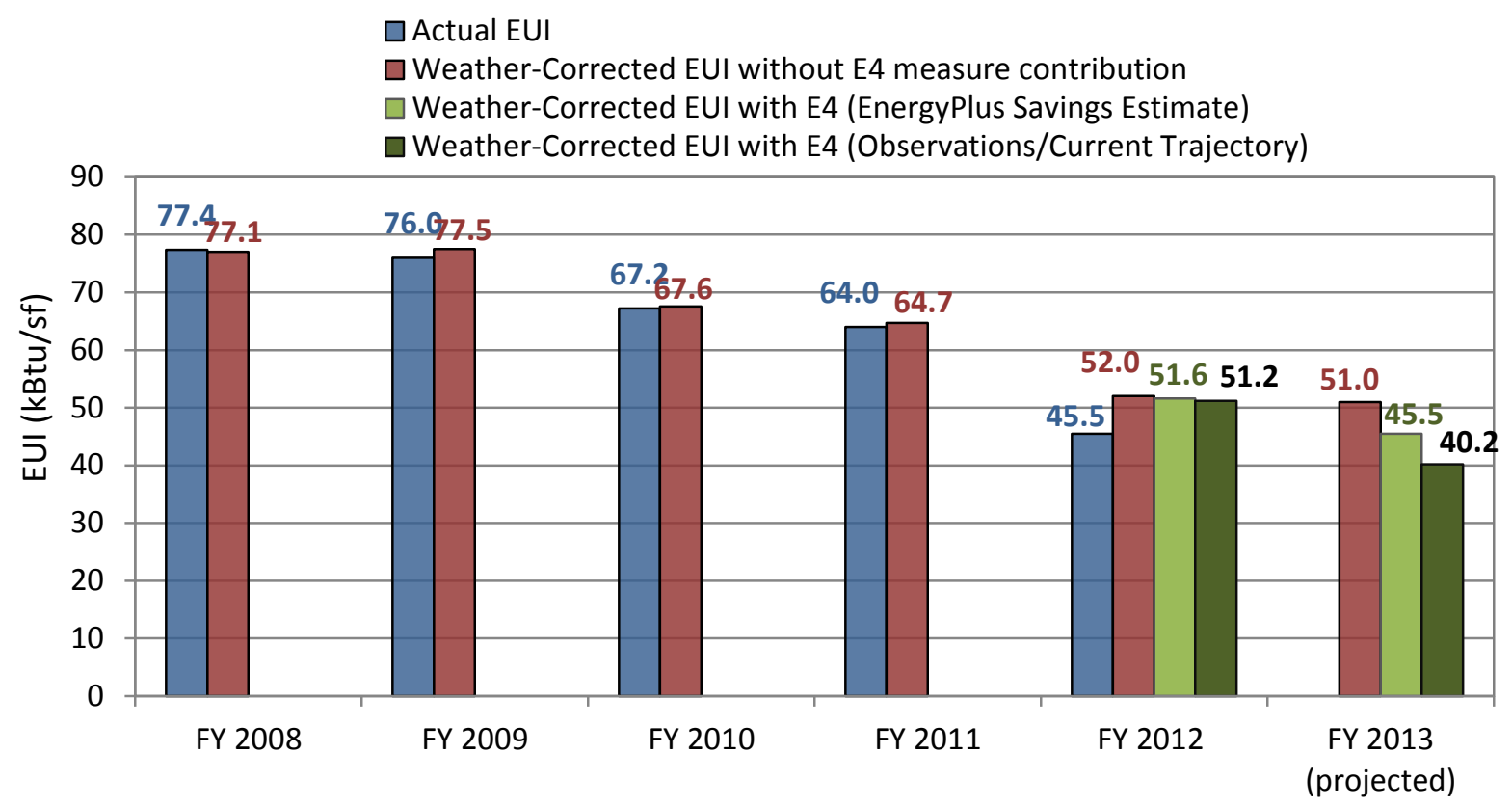

Figure 7. EUI History and Projections for Neal Smith Federal Building 


\subsection{Recommended Monitoring Plan}

This section provides recommendations for continued monitoring and implementation of several of the measures $(2,3,6,7$, and 8) summarized in Section 2 and implemented as part of the Targeted E4 actions taken during FY12.

\section{Measure 2: Static Pressure Reset}

Monitoring Timeframe: Single day in early spring 2013

Neal Smith should target one day in early spring 2013 to test the continuing effectiveness of the static pressure reset algorithm. An ideal time would be during a weather period with highs in the $60 \mathrm{~s}$. Under these weather conditions, very little heating or cooling should be needed, and zone airflow requirements should be low. This should translate to low static pressure set points.

- Make note of current static pressure minimum and maximum set points in Metasys. Do minimum and maximum static pressure set points match the numbers indicated in the implementation details section of the Measure 2 description in this report? If not, can they be set back to those set points or was there a good reason for the change?

- Trend the static pressure set point for 2-3 air handlers over the course of a typical business day (24 hours). Does the static pressure set point stay near the minimum set point or modulate between the minimum and maximum set point (as desired)?

- If the static pressure set point remains stuck at the maximum set point, can the problem be traced? This should only happen if most of the zone dampers are nearly fully open. If this is not the case, is the static pressure reset algorithm enabled?

- Verifying Savings: Trend supply fan power consumption for 24 hours, then set all minimum static pressure set points to be equal to their maximum values and trend power consumption for another 24 hours. Export to a spreadsheet and calculate the time-averaged power consumption for all fans in day 1 and day 2. Sum the average consumption across all fans for day 1 and day 2 . What fraction of fan energy consumption is the static pressure reset saving? $100 \% x$ [1- (day 1 total/ day2 total)]

We expect around 40 percent in the spring/fall and 5-20 percent in the summer/winter. Do not forget to reset the minimum static pressure set points back to their previous set points after this exercise.

\section{Measure 3: Supply Air Temperature Reset}

Monitoring Timeframe: Single day in winter 2012-2013

- Make note of current maximum and minimum supply air temperature set points. Are they all set to $70^{\circ}$ and $55^{\circ} \mathrm{F}$, respectively?

- Trend the supply air temperature set point for 2-3 air handlers over the course of a typical business day ( 24 hours). Does the supply air temperature for each air handler stay near $65-70^{\circ} \mathrm{F}$. If not, try to determine why:

- What is the return air temperature for a given air handler? Compare to the zone temperatures in the air handler's network.

- Is the return air temperature a good approximation of the average zone temperature?

$\circ$ If the return air temperature seems significantly higher than the average zone temperature, increase the low-limit return air temperature in the supply air temperature reset algorithm. 
- Enabling Further Savings: Are all of the zone temperatures comfortable or cool?

- Raise the low-limit return air temperature in the supply air temperature reset algorithm 1 degree each hour until one or two zones border on becoming too warm $\left(75-77^{\circ} \mathrm{F}\right)$.

Measure 6 and 7: Chilled Water Temperature and Differential Pressure Reset

Monitoring Timeframe: Cooling season, one day when the chiller is enabled and highs in the 70's

- Check the chilled water temperature set point and chilled water differential pressure set point during the day when outdoor-air temperatures are moderate and one chiller is running at partial load.

- Chilled water temperature set point should be close to $48-50^{\circ} \mathrm{F}$. Differential pressure set point should be 12-13 psi.

- If the chilled water temperature set point remains close to $44-45^{\circ} \mathrm{F}$, change the chilled water reset algorithm so that the $48^{\circ} \mathrm{F}$ maximum chilled water temperature set point is associated with a higher average chilled water valve signal (currently 20 percent, but raise towards 40 percent).

\section{Measure 8: Wider Deadband}

- $\quad$ Monitoring Timeframe: 1 day in winter or spring 2013

- Make note of current heating and cooling set points for a handful of zones throughout the building. Are the differences in all cases $1^{\circ} \mathrm{F}$ ?

- If possible, trend zone heating requests and zone cooling requests for 10-20 zones throughout the building for one day. Are there any zones that are cycling (switching frequently) between zone heating requests and zone cooling requests? This would indicate that the current deadband is too tight.

- Enabling Further Savings: A 1-degree deadband is still very tight. Raise deadbands to $2^{\circ} \mathrm{F}$, especially in offices and non-critical areas. 


\subsection{Conclusions}

The Neal Smith Federal Building is one of the only facility in Region 6 that has demonstrated continued energy savings since the original E4 audit in 2007. Consumption levels peaked at Neal Smith in early 2009 at $81 \mathrm{kBtu} / \mathrm{sf}$, but dropped to $65 \mathrm{kBtu} / \mathrm{sf}$ by 2011. ARRA projects completed in late 2011, including replacement of old air handlers and installation of new VAV boxes were responsible for a further drop in EUI to about $51.0 \mathrm{kBtu} / \mathrm{sf}$. PNNL conducted an initial site visit for Targeted-E4 in March 2012 and found commissioning of the new air handlers and VAV systems in the process of completion. The new systems were working well, but being operated using very conservative reset strategies or constant set points that presented opportunities for further energy savings. Nine energy saving measures were proposed and all but one were implemented during a follow-up trip in June 2012. An energy model was created in EnergyPlus that predicted that the set of implemented measures would save 10.6 percent, compared to the building's baseline after the ARRA project commissioning. This savings included 5.4 percent electricity savings and 16.9 percent natural gas savings.

Hourly metered data from the ION system was used to compare trends in electricity consumption before and after the E4 measure implementation during 2012 and showed that Neal Smith's post-Targeted-E4 electricity savings were 1.80 times higher than the savings predicted by EnergyPlus for the four months analyzed. The current estimate of annual electricity savings is 9.7 percent.

Natural gas savings were analyzed by comparing consumption from EUAS billing data before and after the E4 measure implementation during the 2012 calendar year which showed that for similar levels of heating demand, Neal Smith was using 39 percent less natural gas from September-December, compared to January-May of 2012.

Neal Smith was one of the top performers in the FY2012 Federal Better Buildings competition and since the competition completed, Neal Smith continues to reduce consumption at a rapid pace. Based on the current savings trends from electricity and natural gas, Neal Smith is expected to reduce annual energy consumption to $40.2 \mathrm{kBtu} / \mathrm{sf}$ by end of FY2013, representing 21.5 percent savings compared to FY2012. This report includes an action plan for the building manager and O\&M contractor to continue to improve the building performance and sustain the savings realized. 